\title{
The Impact of Strategic Fit on the Marketing Performance of the Industrial Corporations in Jordan
}

\author{
Tareq N. Hashem ${ }^{1} \&$ Ahmad Ismaiel Al maani ${ }^{2}$ \\ ${ }^{1}$ Marketing Department, Isra University, Amman, Jordan \\ ${ }^{2}$ Master of public administration program, Modern collage of Business and science (MCBS). Sultanate of Oman \\ Correspondence: Tareq N. Hashem, Marketing Department, Isra University, Amman, Jordan. Email: \\ tareqhashem1975@yahoo.com
}

Received: December 14, 2018

Accepted: January 16, 2019

Online Published: January 25, 2019

doi:10.5539/ijbm.v14n2p115

URL: https://doi.org/10.5539/ijbm.v14n2p115

\begin{abstract}
The present study aimed at identifying the impact of strategic fit on the marketing performance of the industrial corporations in Jordan. The population consists from all the Jordanian industrial corporations that are listed on Amman Stock Exchange. To be specific, the population consists from 63 companies. A sample was chosen through using the simple random sampling method. It was selected from 54 companies. Questionnaire forms were distributed to marketing, and administrative directors (or the ones holding equivalent positions). 76 questionnaire forms were retrieved (out of 108 questionnaires). All of the retrieved forms are valid for statistical analysis. The response rate is $70.37 \%$. The latter rate is considered a good rate.

Several results were concluded. For instance, it was found that the strategic fit has a statistically significant positive impact on the marketing performance of the Jordanian industrial corporations. The researchers recommend providing more attention to the achievement of strategic fit in the industrial corporations. That shall enable those companies to improve their marketing performance.
\end{abstract}

Keywords: strategic fit, marketing performance, external strategic fit, internal strategic fit

\section{Introduction}

Organizations carry out business activities in order to increase their competitiveness. They also carry them in order to provide customers with products of high quality and raise the demand on such products. They also carry them to provide products that meet customer demands. In order to achieve that, organizations seek handling external and internal challenges and risks (Kampker et al., 2014, p. 385).

It should be noted that successful organizations are the ones that seek achieving strategic fit between the external and internal environments. Achieving such fit shall enable organizations to meet the requirements of internal operations. It shall enable organizations to handle the external challenges (Chung, 2017, pp. 21-22).

The problem of the study emerged through the lack of scientific library studies focused on linking the strategic fit with marketing performance, which led to the emergence of the need for such studies in the Jordanian environment.

This study highlighted the importance of strategic fit in industrial corporations in Jordan as the industrial sector is considered one of the leading economic branches in Jordan.

\subsection{Strategic Fit}

Strategic fit plays a significant role in the process of planning for strategic operations. That is because strategic fit enables the organization to introduce new products, and improve its productive capacity. Strategic fit also enables the organization to respond effectively to the changing circumstances. In other words, strategic fit enables the organization to respond to the rapid changes (Aithal, 2016, p. 552)

Slack \& Lewis (2012, p. 281) suggests that strategic fit refers to the fit between the market requirements and the operational capabilities. As for Chung (2017), he suggests that strategic fit refers to the alignment between the organizational resources from one hand and the internal and external operations from another hand.

Schniederjans \& Cao (2009) classifies strategic fit into external and internal strategic fit. External strategic fit 
refers to the alignment between the operational strategy and the business strategy. As for the internal strategic fit, it refers to the alignment between the company duties, practices and policies. Majukwa \& Haddud, (2016) suggest that strategic fit has a significant positive impact on organizational performance. According to Das and Teng $(2000$, p. 21), "Strategic fit is measured in terms of its market relatedness or fit which is necessary to exploit the economies of scope".

Owen et al. (2001, p. 10) suggests that the organizational ability to keep delivering services and products of high quality is considered significant for achieving success on the long-term. Therefore, every business activity aims at achieving strategic fit. Lillis and Sweeney (2013, p. 564) suggest that "many service organizations experience the difficulty of managing the fit between competitive and operations'strategies".

Daniela (2014, p. 530) suggests that many companies are forced to adopt strategies that shape their business future. They suggest that companies must adopt strategies that enable them to achieve a competitive advantage. That shall enable them to survive in the market.

Cruceru and Radulescu (2012) suggest that business strategies are designed and adopted in order to achieve a competitive advantage. The latter researchers suggest that managers are highly concerned in developing the employees' capabilities. Such development shall enable employees to differentiate the company products from the products of its competitors. That shall provide customers with a value (Cruceru \& Radulescu, 2012).

Chopra \& Meindl (2012, p. 21) suggest that alignment must be achieved between response to changes and efficiency. That shall enable companies to achieve a competitive advantage. Many researchers suggest that the organizational strategies, structures and operations must complement one another (e.g. Garengo \& Bernardi, 2007; Cunliffe, 2008; Aagaard, 2016). Achieving such complementarity shall participate in achieving organizational effectiveness. That shall participate in improving performance (Hsieh \& Chen, 2011).

\subsection{Goals of Strategic Fit}

Organizations carry out business activities in order to survive and achieve growth. That can be ensured through adopting business frameworks and improving standards. Achieving strategic fit is a goal sought by all managers in an organization. In addition, it is sought to enable the organizational units to implement the organizational strategies effectively. The achievement of strategic fit must be sought first by the top management. It must be sought then by the other employees working at the organization (Bjorkhem, 2008, p. 13).

Shadid and Al-Nuimi (2012. P. 82) suggest that strategic fit aims at driving the organization towards achieving stability and developing in an ongoing manner. In this context, development refers to the development of the organizational tools and strategies. As for stability, it refers to the state at which the organization is capable of handling any crisis or risk which may be faced while carrying out business operations. The state of stability is reached when the organization is capable to handle any risk related to the target market.

Kim et al. (2015, pp. 370-371) suggest that strategic fit enables the employees to take the environmental circumstances into consideration. They also suggest that strategic fit promotes awareness among employees and directors about the best manner to deal with various types of circumstance. Schott (2008, pp. 22-23) suggests that achieving strategic fit enables organizations to achieve alignment between the organizational plans, and strategies from one hand and the sounding circumstances from another hand. The latter alignment concerns the purchasing power, market status, and the severity of the competitiveness.

Strategic fit aims at promoting interactivity between the organization and other organizations. It also aims at establishing a complementarity relationship between the organization and other organizations. It also promotes fair competition among organizations. In addition, it participates in improving the process of developing the organizational outcomes and activities.

\subsection{The Dimensions of Strategic Fit}

The market environment has been experiencing many changes rapidly. Therefore, organizations must be capable of achieving a strategic fit between the goals and the strategies adopted for meeting the goals. It should be noted that there are several dimensions for strategic fit. These dimensions are: internal and external dimensions (Yusoffa et al., 2016, p. 65).

\section{1) - Internal strategic fit}

Internal strategic fit refers to the extent of alignment between the organizational structure and the strategies adopted. It also refers to the extent of alignment between the organizational activities, events, skills, ideas, and strategies that are adopted with the organization by its leaders, employees and directors.

Internal strategic fit is considered the most important dimension of strategic fit. That is because it affects the 
internal orientation of the organization. Internal strategic fit emphasizes the significant aspects of the internal environment of the organization. That is because emphasizing the latter aspects shall enable the organization to achieve a competitive advantage. It should be noted that the emphasis of the internal strategic fit is more important than the emphasis of the external strategic fit in achieving a competitive advantage (Xu, et al. 2006, p.

\section{2) - External strategic fit:}

According to Kaliappen and Hilma (2017, p. 258), external strategic fit refers to the extent of alignment between the organization and its external environment. In other words, external strategic refers to the extent of alignment and consistency between the organization and its strategies from one hand and the elements of the external environment from another hand. The latter elements include: the market, competitors, competition, customers, market requirements and the promotional campaigns launched by the competitors

\subsection{Marketing Performance}

Organizations seek meeting the goals set in their marketing plans. They seek achieving that in order to raise the organizational market share and achieve growth in the target market in an ongoing manner. Therefore, organizations seeks enforcing control over their performance in an ongoing manner. Such control is enforced through using various methods.

In order to raise the market share and achieve growth, organizations seek assessing their strategic performance. They also seek adjusting their plans in a way that is consistent with the latest developments. Marketing performance can be defined as the extent of meeting the goals that are listed in the marketing plan of a company (Cravens, 1987, p. 22). It can be also defined as the final outcome of an organizational activity (Wheelen \& Hunger, 2008)

Haider (2002) proposes several performance measures in the form of questions. These questions are presented below:

1. What is the value of the current sales volume of the product line?

2. What is the market share value?

3. What is the ratio of the sales distributed through brokers?

4. What is the extent of consumer awareness about the company advertising campaigns?

5. What is the corporate image among consumers and brokers?

6. What is the extent of customer satisfaction with the company products? What is the extent of fulfilling the customer needs through the company products?

7. What is the marketing cost to the total cost ratio?

8. What is the probability for the new product failure? (p. 323)

Agarwal et al. (2003) believes that performance is a multi-dimensional concept. They suggest that there are several performance indicators. These indicators include judgmental and subjective indicators. Judgmental indicators include: customer service, and customer loyalty. Subjective indicators include: return on investment (ROI).

In the light of the aforementioned, it can be clear that it is significant for organizations to achieve a competitive advantage. It should be noted that all organizations seek making marketing plans and strategies in the aim of achieving a competitive advantage and improving their marketing performance. In order to meet such goals, organizations use technology and information systems. The latter systems enable organizations to access the necessary data related to the target market (Adams \& Lamont, 2003).

The Researchers in this study measured marketing performance by using the following main dimensions: (Haider, 2002)

- $\quad$ Market share

- $\quad$ Sales volume

- Company profitability

\section{The Study's Methodology}

The researchers of the present study adopted a descriptive analytical approach 


\subsection{The Study's Population}

The population of the present study consists from all the Jordanian industrial corporations that are listed on Amman Stock Exchange. Based on a list issued by Amman Stock Exchange, the population consists from 63 companies.

\subsection{The Study's Sample}

A sample was chosen through using the simple random sampling method. It was selected from 54 companies. Questionnaire forms were distributed to marketing, and administrative directors (or the ones holding equivalent positions). 76 questionnaire forms were retrieved (out of 108 questionnaires). All of the retrieved forms are valid for statistical analysis. The response rate is $70.37 \%$. The latter rate is considered a good rate.

\subsection{The Instrument's Validity and Reliability}

The instrument's validity was measured. That was done through passing the questionnaire to a panel of experts who are specialized in the study's field. These experts were asked to provide their comments. In the light of their comments, the researchers made several modifications to the study's instrument. Thus, the researchers benefited from their comments to produce the final form of the questionnaire.

In order to measure the instrument's reliability, the researchers calculated the overall value of Cronbach alpha coefficient. The latter value is 0.916 which is a high value. It can be noticed that all the values of Cronbach alpha coefficient are greater than $60 \%$. That indicates that the instrument is highly reliable. It also indicates that the internal consistency of the instrument is high (Malhotra, 2004, p.268).

\subsection{The Normal Distribution Test}

The researchers conducted the (K-S) test to identify whether the data is normally distributed or not. The statistical significance (Sig.) values of the study's variables are greater than $(0.05)$. That indicates that the data is normally distributed (Malhotra, 2004, p .455).

\subsection{Characteristics of the Study's Sample}

Descriptive statistical methods were used to identify the characteristics of the study's sample. Such methods include: frequencies and percentages. The researchers presented below the characteristics of the study's sample:

\section{1)- Gender}

Table 1. Distribution of the study's sample in accordance with gender

\begin{tabular}{lll}
\hline Gender & Total \\
\hline Male & Frequency & 59 \\
& Percentage & $77.6 \%$ \\
Female & Frequency & 17 \\
& Percentage & $22.4 \%$ \\
Total & Total & 76 \\
\hline
\end{tabular}

*Source: The results of the statistical analysis

Based on table 1, it can be noticed that the number of males is greater than the number of females. That indicates that the industrial corporations in Jordan seek recruiting males more than females.

\section{2)- Age}

Table 2. Distribution of the study's sample in accordance with age

\begin{tabular}{|c|c|c|}
\hline \multicolumn{2}{|l|}{ Age } & Total \\
\hline \multirow[t]{2}{*}{ Less than 30 years } & Frequency & 23 \\
\hline & Percentage & $30.3 \%$ \\
\hline \multirow[t]{2}{*}{$30-40$ years old } & Frequency & 26 \\
\hline & Percentage & $34.2 \%$ \\
\hline \multirow[t]{2}{*}{$41-50$ years old } & Frequency & 20 \\
\hline & Percentage & $26.3 \%$ \\
\hline \multirow[t]{2}{*}{ More than 50 years old } & Frequency & 7 \\
\hline & Percentage & $9.2 \%$ \\
\hline Total & Frequency & 76 \\
\hline
\end{tabular}


Based on table 2, it can be noticed that the age of most of the respondents is less than 40 years. That indicates that the industrial corporations in Jordan seek assigning administrative positions to young people.

\section{3)- Academic qualification:}

Table 3. Distribution of the study's sample in accordance with academic qualification:

\begin{tabular}{lll}
\hline academic qualification & & Total \\
\cline { 2 - 3 } Secondary school certificate & Frequency & 1 \\
& Percentage $\% 1.3$ \\
& Frequency & 5 \\
BA degree & Percentage $\% 6.6$ \\
& Frequency & 52 \\
MA degree & Percentage $\% 68.4$ \\
& Frequency $\quad 15$ \\
PhD degree & Percentage $\% 19.7$ \\
& Frequency 3 \\
Total & Percentage $\% 3.9$ \\
\hline
\end{tabular}

*Source: The results of the statistical analysis

Based on table 3, it can be noticed that most of the respondents hold university degrees. Such degrees shall enable them to carry out the tasks and duties assigned to them.

\section{4)- Years of experience:}

Table 4. Distribution of the study's sample in accordance with the years of experience

\begin{tabular}{lll}
\hline Years of experience & & Total \\
\hline Less than five (5) years of experience & Frequency & 15 \\
& Percentage & $\% 19.7$ \\
$(5-10)$ years of experience & Frequency & 14 \\
& Percentage & $\% 18.4$ \\
$(11-15)$ years of experience & Frequency & 17 \\
& Percentage & $\% 22.4$ \\
More than fifteen (15) years of experience & Frequency & 30 \\
& Percentage & $\% 39.5$ \\
Total & Frequency & 76 \\
\hline
\end{tabular}

*Source: The results of the statistical analysis.

Based on table 4 , it can be noticed that most of the respondents $(61.9 \%)$ possess more than ten (10) years of experience.

\section{Results}

Means and standard deviations were calculated to identify the respondents' attitudes. These values are presented below: 


\section{1)- External fit}

Table 5. Means and standard deviations of the statements that concern external fit

\begin{tabular}{lll}
\hline \multicolumn{1}{l}{ Statement } & Mean & Standard deviation \\
\hline $\begin{array}{l}\text { 1)- There are major fluctuations in terms of } \\
\text { the extent of keeping up with the new }\end{array}$ & 4.0000 & 0.97980 \\
$\begin{array}{l}\text { technologies } \\
\begin{array}{l}\text { 2)- The customers are considered sensitive } \\
\text { to the price fluctuations of the products }\end{array}\end{array}$ & \\
$\begin{array}{l}\text { 3)- The needs and desires of customers vary } \\
\text { in the target market }\end{array}$ & 3.0000 & 0.99331 \\
$\begin{array}{l}\text { 4)- There are legal constraints that hinder the } \\
\text { company from providing a variety of }\end{array}$ & 3.9737 & 1.04964 \\
promotional offers & & 1.09512 \\
$\begin{array}{l}\text { 5)- The company have a high sense of social } \\
\text { responsibility towards community }\end{array}$ & 3.9868 & \\
Total & 3.95 & 0.95907 \\
\hline
\end{tabular}

*Source: The results of the statistical analysis.

Based on table 5, it can be noticed that the means are within the range of (3.67-5). It can be also noticed that all the means are high. The overall mean is 3.95. That indicates that the external fit level of the Jordanian industrial corporations is high from the respondent's perspective.

\section{2)- Internal fit:}

Table 6. Means and standard deviations of the statements that concern external fit

\begin{tabular}{lll}
\hline Statement & Mean & Standard deviation \\
\hline $\begin{array}{l}\text { 1)- The work relationships at the company } \\
\text { are characterized with clarity }\end{array}$ & 4.0000 & .92376 \\
$\begin{array}{l}\text { 2)- The management seeks promoting } \\
\text { flexibility }\end{array}$ & 3.9342 & .94284 \\
$\begin{array}{l}\text { 3)- The company complies with all the laws } \\
\text { and regulations that protect the employees' }\end{array}$ & 3.8684 & \\
rights & & 1.09960 \\
$\begin{array}{l}\text { 4)- Awareness is promoted among } \\
\text { employees about all the laws and regulations }\end{array}$ & 3.8816 & \\
that are related to their work at the company & & 1.00621 \\
$\begin{array}{l}\text { 5)- Employees accept the special } \\
\text { circumstances related to work }\end{array}$ & 3.8421 & \\
Total & 3.905 & 1.05896 \\
\hline
\end{tabular}

*Source: The results of the statistical analysis.

Based on table 6 , it can be noticed that the means are within the range of (3.67 - 5). It can be also noticed that all the means are high. The overall mean is 3.905 . That indicates that the internal fit level of the Jordanian industrial corporations is high from the respondent's perspective.

\section{3)- Marketing performance}

Table 7. Means and standard deviations of the statements that concern marketing performance

\begin{tabular}{lll}
\hline Strategic fit participates in: & Mean & Standard deviation \\
\hline 1)- Raising the corporate market share & 4.1842 & .74316 \\
2)- Raising the company sales volume & 3.8684 & .80568 \\
3)- Raising the company profitability & 3.8026 & .78349 \\
Total & 3.9518 & 0.69 \\
\hline
\end{tabular}

*Source: The results of the statistical analysis 
Based on table 7, it can be noticed that the means are within the range of (3.67 - 5). It can be also noticed that all the means are high. The overall mean is 3.9518. That indicates that the marketing performance level of the Jordanian industrial corporationsis high from the respondent' perspective.

\section{Testing the Study's Hypothesis}

\section{Testing the First Hypothesis}

H0.1: Strategic fit doesn't have a statistically significant impact on the marketing performance of the Jordanian industrial corporations

In order to test the first hypothesis, the researchers conducted the multiple regression analysis. The results of the latter analysis are presented below:

Table 8. Results of testing the first hypothesis

\begin{tabular}{lllll}
\hline \multicolumn{3}{l}{ Model Summary } & & \\
Model & $\mathrm{R}$ & R Square & Adjusted R Square & Std. Error of the Estimate \\
\hline 1 & .421 & .177 & .155 & .63440 \\
\hline
\end{tabular}

\begin{tabular}{lllllll}
\hline $\begin{array}{l}\text { ANOVA } \\
\text { Model }\end{array}$ & & Sum of Squares & df & Mean Square & F & Sig. \\
\hline \multirow{4}{*}{1} & Regression & 6.332 & 2 & 3.166 & 7.867 & .001 \\
& Residual & 29.380 & 73 & .402 & & \\
& Total & 35.712 & 75 & & & \\
\hline
\end{tabular}

Based on table 8 , it can be noticed that the $\mathrm{F}$ value is 7 867. It can be noticed that the statistical significance (Sig.) value is less than the statistical significance (i.e. 0.05). That indicates that strategic fit has a statistically significant positive impact on the marketing performance of the Jordanian industrial corporations. The strength of the relationship is 0.421 . As for the $\mathrm{R}$ square, it is 0.177

\section{Testing the Second Hypothesis:}

H0.2: External strategic fit doesn't have a statistically significant impact on the marketing performance of the Jordanian industrial corporations.

In order to test the second hypothesis, the researchers conducted the linear regression analysis. The results of the latter analysis are presented below:

Table 9. Results of testing the second hypothesis

\begin{tabular}{lllll}
\hline \multicolumn{2}{l}{ Model Summary } & & & \\
Model & $\mathrm{R}$ & R Square & Adjusted R Square & Std. Error of the Estimate \\
\hline 1 & .417 & .174 & .163 & .63140 \\
\hline
\end{tabular}

\begin{tabular}{|c|c|c|c|c|c|c|}
\hline \multicolumn{7}{|c|}{ ANOVA } \\
\hline \multicolumn{2}{|c|}{ Model } & Sum of Square & Df & Mean Square & $\mathrm{F}$ & Sig. \\
\hline \multirow{3}{*}{1} & Regression & 6.211 & 1 & 6.211 & \multirow[t]{3}{*}{15.578} & \multirow[t]{3}{*}{.000} \\
\hline & Residual & 29.501 & 74 & .399 & & \\
\hline & Total & 35.712 & 75 & & & \\
\hline \multicolumn{7}{|c|}{ Coefficients } \\
\hline \multirow{2}{*}{\multicolumn{2}{|c|}{ Model }} & \multicolumn{2}{|c|}{ Unstandardized Coefficients } & $\begin{array}{l}\text { Standardized } \\
\text { Coefficients }\end{array}$ & \multirow[t]{2}{*}{$\mathrm{T}$} & \multirow[t]{2}{*}{ Sig. } \\
\hline & & B & Std. Error & Beta & & \\
\hline \multirow[b]{2}{*}{1} & (Constant) & 2.570 & .358 & & 7.186 & .000 \\
\hline & \multicolumn{2}{|c|}{$\begin{array}{l}\text { External strategic } \\
\text { fit }\end{array}$} & .089 & .417 & 3.947 & .000 \\
\hline
\end{tabular}


Based on table 9, it can be noticed that the F value 15.578. It can be noticed that the statistical significance (Sig.) value is less than the statistical significance (i.e. 0.05). That indicates that the external strategic fit has a statistically significant positive impact on the marketing performance of the Jordanian industrial corporations. The strength of the relationship is 0.417 . As for the $\mathrm{R}$ square, it is 0.174 .

\section{Testing the Third Hypothesis}

H0.3: Internal strategic fit doesn't have a statistically significant impact on the marketing performance of the Jordanian industrial corporations.

In order to test the third hypothesis, the researchers conducted the linear regression analysis. The results of the latter analysis are presented below:

Table 10. Results of testing the third hypothesis

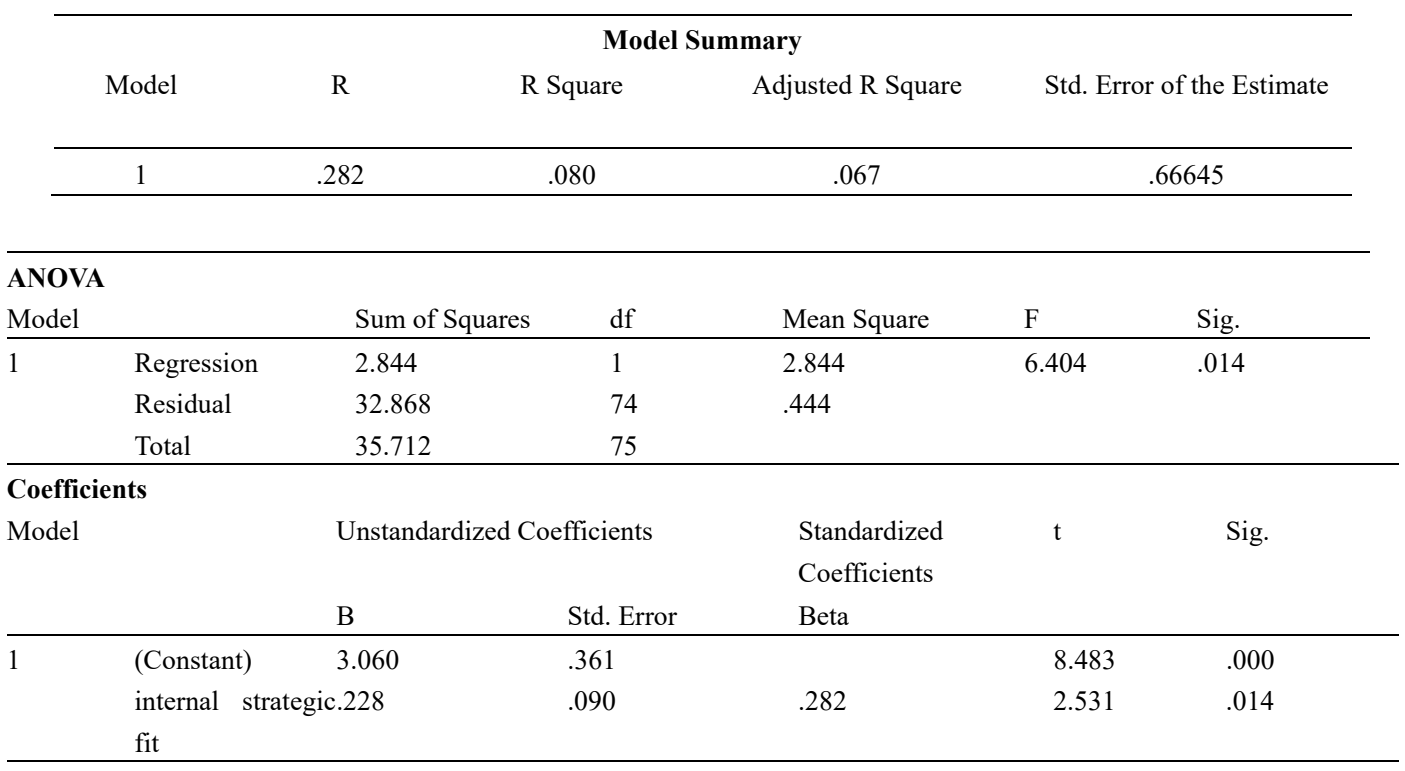

Based on table 10, it can be noticed that the F value 6.404. It can be noticed that the statistical significance (Sig.) value is less than the statistical significance (i.e. 0.05). That indicates that the internal strategic fit has a statistically significant positive impact on the marketing performance of the Jordanian industrial corporations. The strength of the relationship is 0.282 . As for the $\mathrm{R}$ square, it is 0.08 .

\section{Conclusion}

The present study aimed at identifying the impact of strategic fit on the marketing performance of the industrial corporations in Jordan. It aimed to shed a light on strategic fit from a marketing perspective. The researchers aimed to conduct the present study in order to enable the industrial corporations to improve their marketing performance.

It was found that there is a high level of interest in the application of strategic fit both internally and externally, reflecting the high level of awareness among respondents of the importance of strategic fit. Also the availability of strategic fit affects the improvement of marketing performance in the Jordanian industrial corporations. This indicates that strategic alignment is of great importance to the industrial organizations as it contributes to improve their competitiveness and increasing their profitability and market share, thus improving their marketing performance.

The availability of external strategic fit affects the improvement of the marketing performance of Jordanian industrial corporations. The interest in the external environment leads to exploiting existing opportunities in the market and facing threats from competitors, thus improving their marketing performance.

The availability of internal strategic fit affects the improvement of the marketing performance of Jordanian industrial corporations. The interest in the internal environment leads to the exploitation of the strengths of the company and the reduction of weaknesses, which leads to improving the level of their marketing performance.

The latter results are in agreement with the results concluded by (Schott, 2008; Yusoffa et al., 2016; Shadid \& 
Al-Nuimi, 2012; Kim et al, 2015).

\section{The Study's Recommendations}

The researchers recommend keeping up with the latest developments occurring in the external organizational environment by organizations. They also recommend addressing the problems associated with the latter environment by organizations. In addition, they recommend examining and monitoring the internal organizational environment by organizations. Monitoring the latter environment shall enable organizations to identify their weaknesses and strengths that are related to the latter environment. Identifying such weaknesses and strengths shall enable organizations to conduct external and internal strategic fit analysis efficiently. That shall enable organizations to improve their marketing performance level.

The researchers recommend conducting similar studies targeting other business sectors. That shall enable the companies operating in other sectors to improve their marketing performance. In addition, the researchers recommend providing more attention to the strategic fit in the industrial corporations. That shall enable those companies to improve their marketing performance

\section{References}

Aagaard, A. (2016). Sustainable Business. Integrating CSR in Business and Functions. Gistrup: River Publishers.

Adams, G. L., \& Lamont, T. (2003). Knowledge Management Systems and Developing Sustainable Competitive Advantage. Journal of Knowledge Management, 7(2), 142-154.

Agarwal, S., Erramilli, M. K., \& Chekitan, S. D. (2003). Market orientation and performance in service firms: role of innovation. Journal of Services Marketing, 17(1), 68-82.

Aithal, S. (2016).A Study on Strategic Fit in Supply Chain. International Journal of Advanced Research in Computer Science and software Engineering, 6(6), 551-553.

Bjorkhem, M. (2008), Does strategic fit result in better fitting and more successful employees? Master thesis, Baltic Business School.

Chopra, S., \& Meindl, P. (2012). Supply chain management: Strategy, planning and operation. Upper Saddle River, NJ: Pearson/Prentice Hall.

Chung, D. (2017). The Impact of Strategic Fit on Innovation Performance: Focusing on Manufacturing Industry, Ph. D. Dissertation in Engineering, Seoul National University.

Cravens, D. (1987). Strategic Marketing. Illinois, JRWIN.

Cruceru, A., \& Radulescu, V. (2012). Achieving marketing success through strategic orientation of the organization. Romanian Journal of Marketing, 4, 29-32.

Cunliffe, A. L. (2008). Organization Theory. London: Sage Publications

Daniela, P. A. (2014). Competitive advantage in the enterprise performance. Annals of the University of Oradea, Economic Science Series, 23, 524-531.

Das, T., \& Teng, B. S. (2000). A resource-based theory of strategic alliances. Journal of Management, 26, 31-62.

Garengo, P., \& Bernardi, G. (2007). Organizational Capability in SMEs - Performance Measurement as a Key System in Supporting Company Development. International Journal of Productivity and Performance Management, 56(5/6), 518-532

Haidar, M. (2002). The information systems-an approach towards achieving a competitive advantage. Al-Dar Al-Jame'eya Publishing House. Alexandria.

Hsieh, Y. H., \& Chen, H. M. (2011). Strategic Fit among Business Competitive Strategy, Human Resource Strategy, and Reward System. Academy of Strategic Management Journal, 10(2), 11-32.

Kaliappen, N., \& Hilman, H. (2017). Competitive strategies, market orientation types and innovation strategies: finding the strategic fit. World Journal of Entrepreneurship, Management and Sustainable Development, 13(3), 257-261.

Kampker, A., Burggräf, P., \& Nee, C. (2014). Strategic fit: Overview of cost, quality and scalability impact on the added value network in electric engine production. In Advanced Materials Research (Vol. 907, pp. 379-389). Trans Tech Publications.

Kim, M. J., Lee, J., \& Park, J. Y. (2015) The Effect of Cooperation-Strategy Fit on the Performance of Subcontractors-Focused on Samsung Electronics' Subcontractors. JOEBM, 3(3), 370-376. 
Majukwa, D., \& Haddud, A. (2016). Operations management impact on achieving strategic fit: A case from the retail sector in Zimbabwe. Cogent Business \& Management, 3(1). https://doi.org/10.1080/23311975.2016.1189478

Malhotra, N. K. (2004). Marketing research. New Jersey: Prentice Hall

Owen, K., Mundy, R., Guild, W., \& Guild, R. (2001). Creating and sustaining the high performance organization. Managing Service Quality: An International Journal, 11, 10-21.

Schniederjans, M., \& Cao, Q. (2009). Alignment of operations strategy, information strategic orientation, and performance: An empirical study. International Journal of Production Research, 47, 2535-2563.

Schott, C. (2008). The influence of the organizational climate-strategy fit on strategic behaviourv: mediated by affective commitment and moderated by the strength of HR climate (Bachelor's thesis, University of Twente).

Shadid, E. O., \& Al-Nuiami, M. (2012). Measuring the Effect of Strategic Fit between Adaptive Competitive Strategy and Business Intelligence in Achieving Organizational Excellence: An Empirical Study on Jordanian Insurance Companies. Middle East University.

Slack, N., \& Lewis, M. (2012). Operations strategy. Edinburg: Pearson Education.

Wheelen, L., \& Hunger, J. ( 2008). Strategic Management and Business Policy. Pearson Education Inc., Upper Saddle River, New Jersey, 11 th Ed.

Xu, S., Cavusgil, S. T., \& White, J. C. (2006). The impact of strategic fit among strategy, structure, and processes on multinational corporation performance: A multimethod assessment. Journal of International Marketing, $14(2), 1-31$.

Yusoffa, Y. B. M., Asharia, H. B., \& Bin, M. N. (2016). Strategic Fit and Supply Chain Performance (SCP): The Effect of Supply Chain Management (SCM) as the Mediator. ISSC. ISSC 2016: International Soft Science Conference.

\section{Copyrights}

Copyright for this article is retained by the author(s), with first publication rights granted to the journal.

This is an open-access article distributed under the terms and conditions of the Creative Commons Attribution license (http://creativecommons.org/licenses/by/4.0/). 